JOURNAL OF ISLAMIC EDUCATION

Vol. 6 No. I May 202 I

P-ISSN 2503-5363; E-ISSN 2528-0465

http://www.ejournal.stitmuhbangil.ac.id/index.php/jie

\title{
The Prophet Muhammad Saw the Wisdom of the Prophet's Miracles
}

\author{
*Dewi Suryani Djamduri ${ }^{1}$, Mutia Dara Malinda ${ }^{2}$ \\ ${ }_{1,2}$ (Universitas Ibn Khaldun Bogor, Jl. Sholeh Iskandar, Bogor) \\ dewi.suryani@uika-bogor.ac.id
}

\begin{tabular}{|c|c|}
\hline Informasi Artikel & Abstract \\
\hline $\begin{array}{l}\text { Received: } \\
1 \text { February } 2021\end{array}$ & $\begin{array}{l}\text { The Prophet Muhammad SAW is a role model of } \\
\text { all Muslims. The miracles from Allah, the Almighty } \\
\text { to gave him is a proof for his Prophetic. As }\end{array}$ \\
\hline $\begin{array}{l}\text { Accepted: } \\
7 \text { April } 2021\end{array}$ & $\begin{array}{l}\text { Muslims we must believed and take lesson from } \\
\text { it, because those all provisions of Allah, the } \\
\text { Almighty has given. This reseach is a qualitative }\end{array}$ \\
\hline $\begin{array}{l}\text { Published: } \\
5 \text { May } 2021\end{array}$ & $\begin{array}{l}\text { reaseach and aims to get more known about the } \\
\text { lesson of the miracles of Prophet. It is used } \\
\text { document research to get the aims and with }\end{array}$ \\
\hline $\begin{array}{l}\text { Keywords: } \\
\text { The Prophet Muhammad, } \\
\text { The miracle of Prophet, } \\
\text { The wisdom of Miracle }\end{array}$ & $\begin{array}{l}\text { study looks at the verses of the Holy Qur'an, } \\
\text { Hadiths, some previous study and books. The } \\
\text { miracles of Prophet Muhammad SAW that have } \\
\text { from Allah, the Almighty always have the reasons } \\
\text { and from it this articles can find the answer of } \\
\text { lesson in life and as guided in Allah's path. The } \\
\text { result of this research are expected to helps all } \\
\text { Muslims more better understand and deepen } \\
\text { what the Prophet Muhammad conveyed as the } \\
\text { Messenger of Allah. }\end{array}$ \\
\hline
\end{tabular}

\section{Pendahuluan}

A miracles is an event or action accours beyond human reason which Allah has given to his prophets. Since a long time ago, most people considered Miracle as an event in the external world brought about by the immediate agency or the simple volition of God, operating without the use of means capable of being discerned by the senses, and designed to authenticate the divine commission of a religious teacher and the truth of his message (Umar Sidiq, 2018). They had doubted and accused God's greatness of being a trick. It 
is like, when the Prophet Muhammad was asked to show the proofs as the messeger of Allah. The miracle is a proof, Islam is a religion which is only admitted by Allah, theAlmighty (Adam, 2009).

The Prophet Muhammad SAW is a role mode for all Muslims in this world and he the last of prophets in Islam (Al-Buthy, 2003). He was born in Macca on Monday, 12th Rabiul Awwal of the Elephant Year or 20 April $571 \mathrm{M}$. The son of Abdullah bin Abdul Muththalib and Aminah binti Wahab. The parents of Prophet Muhammad died when he was a child. His charaters and act always faced to Allah SWT. The Prophet Muhammad always guiding his people to be together faced to Allah's path. For do it, he was facing with many obstacles and distractions from the people who hate the religion of Allah.More than 14 centuries passed, his influences are still very strong for Muslims (Hart, 2012). With faith and determination, he always under protection from Allah and to make other people for believe, he is a messenger, Allah give him many miracles to prove it.

All muslims know the most famed of miracles Prophet's Muhammad and known as the holy book to guide muslims, The Al-Qur'an. At the time of the Prophet Muhammad SAW, it was considered the golden age of Arabic literature (Yanggo, 2016), because of thet was the prophet's greatest miracle in the form of a book to guides human life until the end of world. The Al-Qur'an is clear evidence and event not one a book or anything can same like it. The verses are the words or utterences of Allah, the Almighty directly to Muhammad in guiding his people towrds Shirathal Mustaqim (Ikhwan, 2020).

The Al-Qur'an has explained all the events was occurred in the past and tells about the miracles was Allah gave to the Prophet Muhammad and other prophets. This evidence has been discribed and even admitted by experts as strong concrete evidence. However, until now there are still many people, even Muslims who do not take the meaning and the wisdom contained in the Holy Qur'an (Anwar, 2021). 
This Article aims to more examine the miracles of Prophet's Muhammad SAW as a proof of the Allah's messeger and expalin the meaning and wisdom contained therein. The writters hope this examine can help for Muslims to more and more faced to Allah, the Almighty path.

\section{METODE PENELITIAN}

The method uses for this article is a qualitative method with a descriptive analysis approach and literature review. This type of qualitative descriptive research is a research method that utilizes qualitative data and is described descriptively, this research is used to analyze events, phenomena, or situations socially, and literature review (Creswell, 2015). A qualitative research is an attempt to present the social world, and its perspectives on the world, in terms of concepts, behavior, perceptions, and problems about the human being studied (Arikunto, 2002).

\section{TEMUAN DAN PEMBAHASAN}

\section{The Miracles of Prophet's Muhammad}

The Prophet Muhammad SAW is a noble human being who became the last Prophet and Messenger of Muslims. The Prophet Muhammad SAW also has several mandatory characteristics, such as Shidiq (honest), Tabligh (conveying), Amanah (believing) and Fathonah(intelligent). That make him as the greats leader and the greats role mode on Muslims (Syam, 2017). In addition, the Messenger of Allah was also provided by Allah SWT with various kinds of amazing miracles.As a gift from Allah, the Almighty, its are a ways of Allah SWT to protected and guided the prophet to tells all humans, that Islam is the only one true religion.

At first time for the Prophet Muhammad SAW showed his miracles to the unbelievers who doubted himself to be a Massager of Allah, it is split the moon. The Prophet Muhammad SAW showed his miracle to people in Mecca doubted 
him. With the permission from Allah SWT, he split the moon into two parts. This phenomenon is discribed in a hadith sahih al-Bukhari,

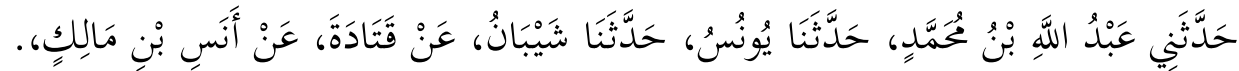

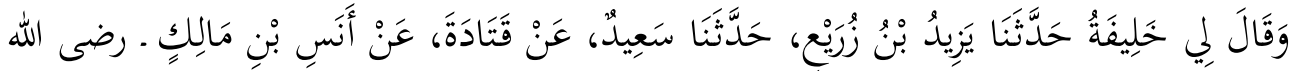

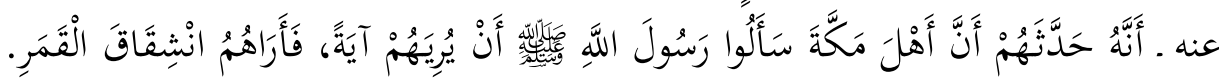

From the hadith explains, that the companions of the Prophet at that time were withnesses of the greatness of God. And in the Holy Qur'an on Surah Qamar verses 1-6,Allah said,

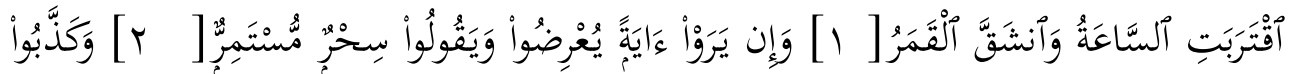

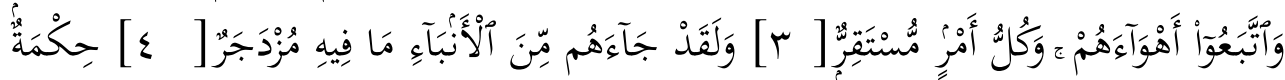

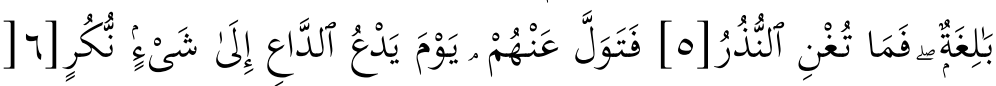

"[1] The Hour has drawn near and the moon was split into two. [2] Yet, whenever they see a sign, they turn away, saying, "Same old magic!" [3] They rejected 'the truth' and followed their own desires-and every matter will be settled- [4] Even though the stories 'of destroyed nations' that have already come to them are a sufficient deterrent. [5] This Quran is profound in wisdom, but warnings are of no benefit to them. [6] So turn away from them ' $O$ Prophet'. 'And wait for' the Day 'when' the caller will summon 'them ' for something horrifying."

The meaning from that verses are when The Prophet Muhammad showed his miracle, the unbelieve people still denied the truth and warning from Allah, the Almighty.

The other proof of the splitting of the moon has been shown by NASA, which found traces of the splitting of the moon (Khalil, 2020). The photos of it has been scattered on various internet sites. 
At various other times, The Prophet Muhammad SAW showed his other miracles, like Water flowed from his fingers. This was happening when the time of Asr' prayer, at that time, all Muslims who want to prayer can't find water for ablution. So, the Prophet Muhammad SAW brought a pot and inside it's full of water. It described in a hadith sahih al-Bukhari,

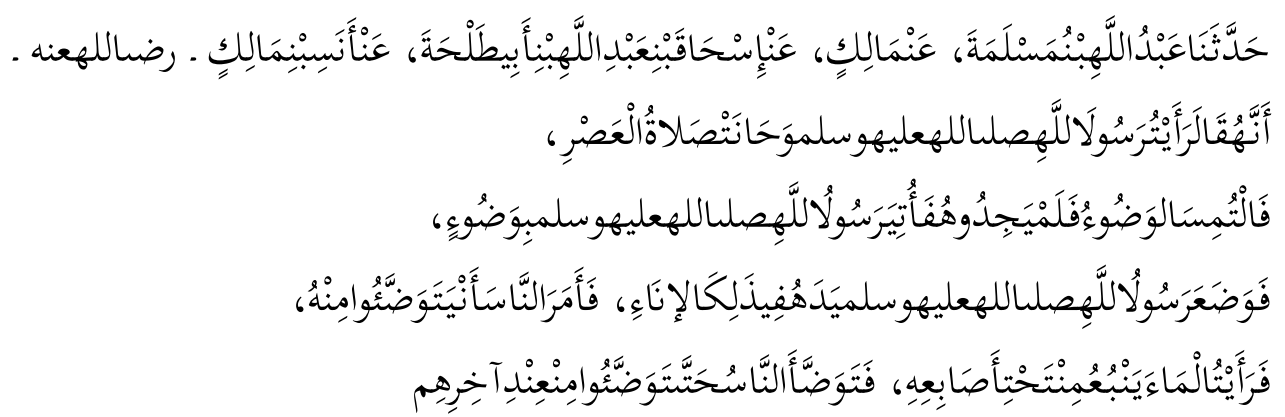

"Narrated Anas bin Malik:

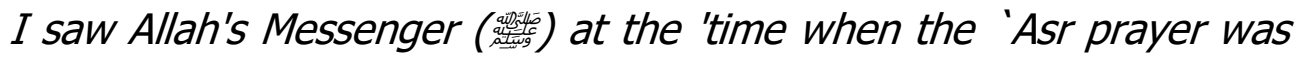
due. Then the people were searching for water for ablution but they could not find any. Then some water was brought to Allah's

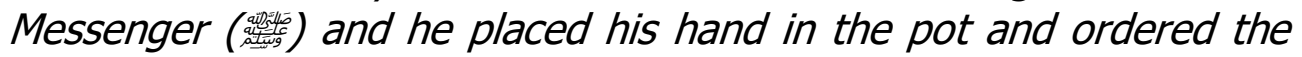
people to perform the ablution with the water. I saw water flowing from underneath his fingers and the people started performing the ablution till all of them did it"[Bukhari:3573].

And other miracles are, the Prophet Muhammad SAW prayed to Allah SWT for rain. It's because of a man come when the Prophet Muhammad was da'wah on Friday and he told to the Messenger for prayer to Allah, because many his farms died. The Prophet did it for fulfill the request for the man, and Allah grant it. It described in a hadith,

"Narrated Anas:

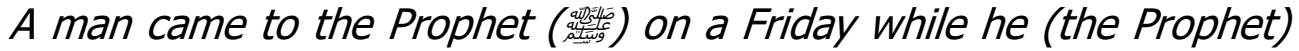
was delivering a sermon at Medina, and said, "There is lack of rain, so please invoke your Lord to bless us with the rain." The Prophet

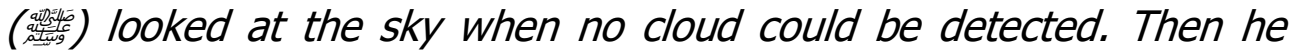
invoked Allah for rain. Clouds started gathering together and it rained till the Medina valleys started flowing with water. It continued raining till the next Friday. Then that man (or some other man) stood

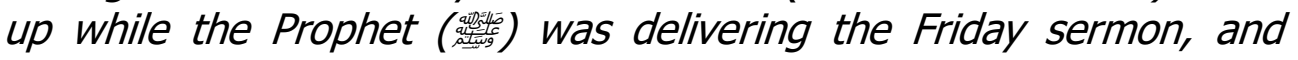


said, "We are drowned; Please invoke your Lord to withhold it (rain) from us" The Prophet smiled and said twice or thrice, "O Allah! Please let it rain round about us and not upon us." The clouds started dispersing over Medina to the right and to the left, and it rained round about Medina and not upon Medina. Allah showed them (the people) the miracle of His Prophet and His response to his invocation"[Bukhari :6093].

The next miracle of the Prophet Muhammad is Isra Mi'raj. This Miracle is one of the well-known and considered a day of commemoration for Muslims which coincides every 27th of Rajab. Before Isra Mi'raj, the Prophet Muhammad SAW was in a condition of mourning because the two people he loved died, his uncle, Abu Thalib and his wife, Khadijah. The passing of the two persons he loved made the Quraish more courageous to interfere with the prophets preaching (Sadiman \& Karolina, 2017). In the year of 'Amul Huzn (sadness year), Allah SWT gave him the miracle, that the Isra Mi'raj. Isra Mi'raj is the prophet Muhammad's journey at night from Masjidil Haram in Mecca to Masjidil Aqsa in Jarusalem and proceed to Sidratul Muntahaor the seventh heaven, an unseen place that cannot be captured by human sanses. When the Prophet Muhammad SAW was Mi'raj, he given orders from Allah, the Almighty, said to all Muslims to Prayer five times a day. This miracle is explained on The Holy Qur'an, Surah Al-Isra verse 1, Allah said;

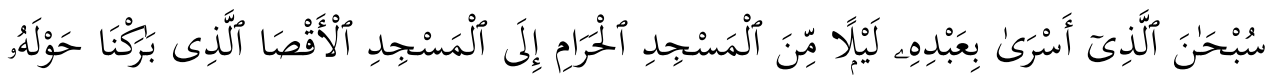

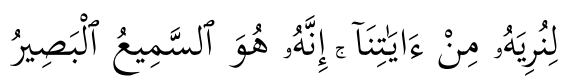

"Exalted is He who took His Servant [i.e., Prophet Muhammad ( by night from al-Masjid al-Harām to al-Masjid al-Aqșā, whose surroundings We have blessed, to show him of Our signs. Indeed, He is the Hearing, the Seeing."

The Last is the biggest of Prophet's Miracles and the guided book to all Muslims, The Holy Qur'an. From all Miracles was Allah SWT gave to Allah's Prophet, The Holy Qu'ran is the best and the last miracles for all Muslims still can see and feel until now and until end of this world. Its existence is one of 
the things that must be believed by all Muslims. In the order of faith, Al-Qur'an is placed in third place and its posisition is more exalted than the Propeths of Allah. The Holy Qur'an itself is all the words of Allah in guiding Muslims to always be on the path and protection Allah, it is mediated by the angel Gabriel and accepted by the Prophet Muhammad SAW as the human trust of Allah. Its contents explain the greatness of Allah, the promises and warnings for Muslims (Saidah, 2013). There no other book that resembles it, morever to competed with the Holy Qu'ran. There is no need for any more doubts, the proofs of the Al-Qu'ran as the greatest miracle.Allah SWT said,

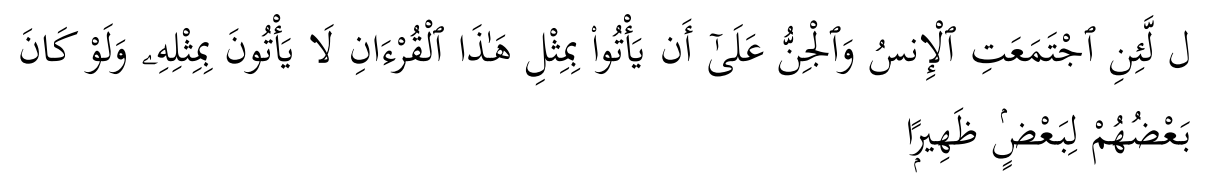

Say, "If mankind and the jinn gathered in order to produce the like of this Qur'ann, they could not produce the like of it, even if they were to each other assistants. "[al-Isra, 88].

Allah, the Almighty even emphasizes his greatness through the contents of this verse. No one Allah SWT creatures can make same like the Holy Quran.

From the Miracles and the stories of miracles, its all have meaning. The provisions of Allah, the Almighty, both kauni and syar'i, are always filled with wisdom. There is not a single matter that Allah, the Almighty, predestines but is full of profound wisdom. Likewise, the miracles that Allah, the Almighty, gave to His prophets and messengers, were not in vain. Various wisdoms and benefits surround the miracles of prophets and messengers. Among its the wisdoms and benefits are;

1. As A Prophetic Evidence

Like writter said before, Allah, the Almighty gave miracle to His prophets as to said they are the messenger of Allah. This can be seen, when the Prophet Muhammad SAW showed his miracle to split the moon by Allah's permission. This made sure that he was the messenger of Allah. For Muslims this is a faith. 
2. As Strengthen Faith

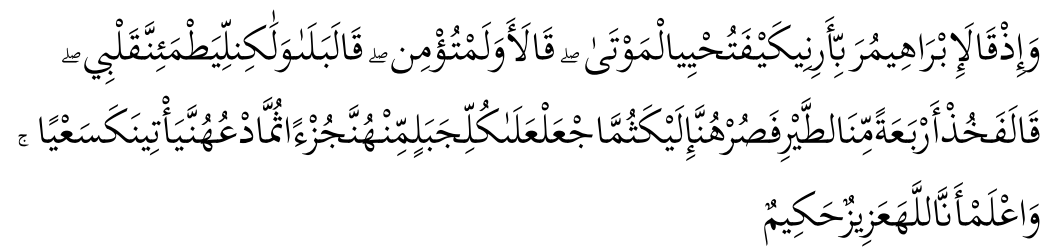

And [mention] when Abraham said, "My Lord, show me how You give life to the dead. " [Allah] said, "Have you not believed?" He said, "Yes, but [I ask] only that my heart may be satisfied." [Allah] said, "Take four birds and commit them to yourself.1 Then [after slaughtering them] put on each hill a portion of them; then call them - they will come [flying] to you in haste. And know that Allah is Exalted in Might and Wise." [Al-Baqarah, 260].

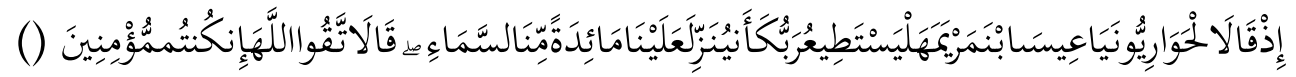

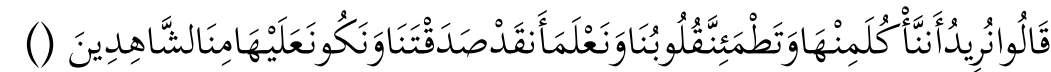

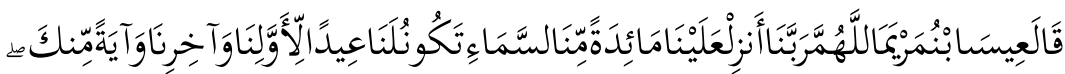

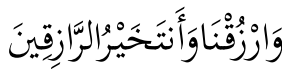

[And remember] when the disciples said, "O Jesus, Son of Mary, can your Lord1 send down to us a table [spread with food] from the heaven?" [Jesus] said, "Fear Allah, if you should be believers. "They said, "We wish to eat from it and let our hearts be reassured and know that you have been truthful to us and be among its witnesses." Said Jesus, the son of Mary, "O Allah, our Lord, send down to us a table [spread with food] from the heaven to be for us a festival for the first of us and the last of us and a sign from You. And provide for us, and You are the best of providers. '[Al- Mai'dah, 112-114].

the two verses explained, the miracle make someone to more believe to Allah, the Almighty. Even thought he is Allah's prophet. As Muslims, its important things to always in Allah's side.

3. As A Guide of Life

From all stories from the Allah's Prophets, miracles can be guided and hints of life. When someone in bad contitons, Allah will answer the problems by Al-Qur'an. When you in good conditons, Allah will warned to overdo it. In the Holy Qur'an, all things that will happen have explained by Allah. If you always 
read it, what you want and need always written on the Holy Qur'an. Allah SWT said,

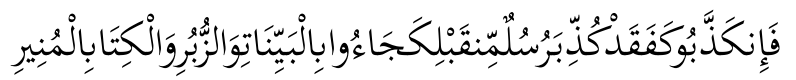

Then if they deny you, [O Muhammad] - so were messengers denied before you, who brought clear proofs and written ordinances and the enlightening Scripture [Al-Imran, 184].

\section{KESIMPULAN}

all decision of Allah, the Almighty always have a wisdom. It is can be absorbed by others and someone itself. Even in every incident is beyond human reason, like the miracles of the prophets. All things in the world have been arranged and established by Allah and as humans, we only have to choose to be followers of Islam or to oppose it in the path of infidelity. There is no God who can be worshiped but Allah and there is no other doubt about his creation. Seeing all the lessons that can be taken, we as Muslims are very happy. No other people can feel this happiness. Therefore, make the meaning of this wisdom as a guide and strength for us to face the trials that arise. Patience and obedience are the keys in its implementation.

\section{BIBLIOGRAFI}

[1] Adam, M. (2009). Ma'rifaturrosul-Kenali dan Cintai Nabimu Pasti Tidak akan Sesat dan Menyesatkan. Bandung: Ma'rifat.

[2] Al-Buthy, M. S. R. (2003). Sirah Nabawiyah. Penj. Aunur Rafiq Shaleh Tamhidi. Jakarta: Robbani Press.

[3] Anwar, S. (2021). Internalisasi Nilai Pendidikan Akhlak dalam Surat AlHujurat Tafsir fi ZIlalil Qur ' an. JIE: Journal of Islamic Edication, 6(1), 112.

[4] Arikunto, S. (2002). Prosedur Penelitian Suatu Pendekatan Praktek. Jakarta: Rineka Cipta.

[5] Creswell, J. (2015). Educational Research, Planing, Coducting and Evaluating Quantitative. Jakarta: Pustaka Pelajar.

[6] Hart, M. H. (2012). 100 Tokoh Paling Berpengaruh di Dunia. Jakarta 
Selatan: Noura Books (PT Mizan Publika).

[7] Ikhwan, A. (2020). Development of Educational Resources in Junior High Schools to Obtain Quality. Cendekia: Jurnal Kependidikan Dan Kemasyarakatan, $18(1)$, $1-16$. https://doi.org/https://doi.org/10.21154/cendekia.v1i1.1897

[8] Khalil, O. (2020). The Evidence of the Split of the Moon. International Journal of Astronomy, 9(1), 1-12.

[9] Sadiman, \& Karolina, A. (2017). Pendekatan Saintific Quantum Dalam Memahami Perjalanan Isra' Nabi Muhammad Saw. FOKUS:Jurnal Kajian Keislaman Dan Kemasyarakatan, 2(2), 200-225.

[10] Saidah, N. (2013). Bidadari Dalam Konstruksi Tafsir Al-Qu'an. PALASTREN: Journal IAIN Kudus, 6(2), 441-472.

[11] Syam, R. S. (2017). Prophetic Leadership: The Leadership Model of Prophet Muhammad in Political Relation of Social. Ummah. Jurnal Pendidikan Islam, 6(2), 371-396.

[12] Umar Sidiq, L. I. (2018). Inclusive Curriculum Education Modification Management (Case Study at Ponorogo National Immersion Primary School). Al-Hayat: Journal of Islamic Education, 02(02), 1-11.

[13] Yanggo, H. T. (2016). Al-Qur'an Sebagai Mukjizat Terbesar. WARATSAH: Jurnal IImu-IImu Keislaman Dan Sosiolinguistik, 1(2), 126. 